LAW IN MANY SOCIETIES 



\title{
LAW IN MANY SOCIETIES
}

\author{
A Reader
}

EDITED BY

LAWRENCE M. FRIEDMAN,

ROGELIO PÉREZ-PERDOMO,

AND MANUEL A. GÓMEZ 
Stanford University Press

Stanford, California

(C)2011 by the Board of Trustees of the Leland Stanford Junior University. All rights reserved.

No part of this book may be reproduced or transmitted in any form or by any means, electronic or mechanical, including photocopying and recording, or in any information storage or retrieval system without the prior written permission of Stanford University Press.

Printed in the United States of America on acid-free, archival-quality paper.

Library of Congress Cataloging-in-Publication Data

Law in many societies : a reader / edited by Lawrence M. Friedman, Rogelio Pérez-Perdomo, and Manuel A. Gómez. pages $\mathrm{cm}$

Includes bibliographical references and index.

ISBN 978-0-8047-6373-8 (cloth : alk. paper)--ISBN 978-0-8047-6374-5 (pbk. : alk. paper)

1. Sociological jurisprudence. I. Friedman, Lawrence M. (Lawrence Meir), 1930- editor of compilation.

II. Pérez-Perdomo, Rogelio, editor of compilation. III. Gómez, Manuel A. (Manuel Alejandro), 1971- editor of compilation.

K376.L384 2011

340 '.115--dc22

2010048550

Typeset by Bruce Lundquist in 10/13.5 Minion 
To Leah

To Andrea, Sofia, and Camila

To Maria, Marco, Max, and Miriam 
